\title{
Deforestation and Changes in People's Economies Due to Oil Palm Plantations in East Kalimantan
}

\author{
${ }^{1}$ Ramadhan Dwi Purwanto, ${ }^{2}$ Alam Mahadika \\ Program Study Government Science, University Muhammadiyah Of Yogyakarta \\ mahadikaalam@gmail.com
}

\begin{abstract}
Abstraksi.
Permintaan pasar yang cukup tinggi terhadap minyak kelapa sawit, menyebabkan busnis ini sangat menguntungkan. Tingginya permintaan ini menyebabkan penanaman kelapa sawit secara masif di wilayah Kalimantan Timur dan menciptakan terjadinya eksploitasi tanah. Ditambah lagi, konsep penanganan kemiskinan yang diteteapkan oleh pemerointah Kalimantan Timur dengan menitikberatkan pemecahannya kepada lapangan kerja pada pengelolaan perkebunan kelapa sawit, semakin menambah persoalan baru yang menarik untuk dibahas dalam tulisan ini. Penelitian ini dilakukan dengan metode diskriptif kualitatif. Dan hasil dari penelitian yang telah dilakukan antara lain 1) Peluang kerja baru telah menimbulkan persoalan berupa kerentanan ekoonomi di masyarakat terkait dengan kesalahpahaman terhadap konsep kemiskinan dan addanya ketidaktahuan yang mendasar, 2) Wilayah Kalimantan Timur hanya menawarkan tanah tanpa memikirkan tentang akses pendidikan, kesehatan dan asuransi keberlangsungan perusahaan, 3) Perubahan kehidupan hanya bergantung pada satu produk yaitu minyak kelapa sawit, 4) Eksploitasi terhadap tanah terus berpengaruh terhadap berkurangnya hutan di Kalimantan Timur dimana merugikan terhadap keberagaman jenis tanaman, hewan dan komunitas.
\end{abstract}

Kata Kunci : Penggundulan hutan, kebergantungan, minyak kelapa sawit.

\begin{abstract}
.
The market demand for oil palm commodities does make the plantation business a very profitable endeavor. The high demand led to the massive clearing of oil palm plantations in East Kalimantan that resulted in land exploitation. In addition, the concept of poverty alleviation by the government in East Kalimantan by relying on employment from palm oil plantations then added a new problem that is deforestation and changes in the local people's system to be discussed in this journal. This research uses qualitative descriptive. The result in the Get is 1.) The job opening brought about a new problem of community economic vulnerability due to an error in understanding the concept of poverty and the existence of fundamental source of blindness. 2.) East Kalimantan Region is only a land that is not followed by access to education and health and the assurance of a decent life for the company. 3.) The change of the living system depends only on one commodity of oil palm 4.) The exploitation of this land has an ongoing impact on deforestation in East Kalimantan, which is detrimental to the existence of diversity of plants, animals and local communities.
\end{abstract}

Keywords: Deforestation, dependence, living, oil palm oil.

\section{Introduction.}

This paper will discuss the problem of land exploitation that occurs in Indonesia, especially in East Kalimantan Province due to land exploitation by oil palm plantations. In the period 2009-2013, Indonesia's forests lost an area of 1.13 million hectares annually or equivalent to 3 times the area of a football field per minute (ForestWatch Indonesia 2018). Other research also 
shows that the entire island of Kalimantan from the period 2000 to 2017 found 6.04 million hectares of old forest has been lost(CIFOR 2019). In the same period industrial plantations increased overall by $170 \%$, or 6.20 million hectares, of which $88 \%$ for oil palm and $12 \%$ for pulpwood (Ibid.). This bare forest eventually turned together into oil palm plantations by the company. Then we shift to East Kalimantan Province which has an area of 12.9 million hectares with a composition of 9.5 million hectares of remaining forest area in 2015 (INCAS, 2015). This area has a high number of land cover that is 84 thousand hectares in 2013 to 157 thousand hectares in 2016,this figure doubled (FWI 2018). In fact, this province is the territory that will become the new capital of the Republic of Indonesia. Deforestation in East Kalimantan will continue to increase from year to year mainly due to land exploitation by space-greedy corporations.

The land expansion is not without a definite reason if there is no very high market demand for palm oil. In fact, people's need for palm oil is not just for the production of cooking oil. Palm oil is also an ingredient to make ice cream, cheese, salad dressing, chocolate, pharmaceuticals, soap, cosmetics, oleochemicals(Khatun et al 2017) This means that palm oil is already one of the mixed ingredients that are often used in our daily lives. Based on the Regulation of the Minister of Mineral Resources (ESDM) of the Republic of Indonesia Number 41 of 2018 states that the use of palm oil is also used in the mixture of Fuel Oil (BBM) through the policy of the use of Biofuels or Biofuels $(\mathrm{BBN})$. Biofuel is one of the alternative energy solutions used to minimize the use of fossil energy. Even legally, the government has supported the use of biofuels through the Regulation of the Minister of Energy and Mineral Resources No. 12 of 2015 with the determination of a minimum obligation of $20 \%$ determination and will continue to increase. So the need for land and production also increased.

Due to deforestation and exploitation of land such as this will greatly impact the environment such as ecology, land conflicts and agrarian resources, environmental pollution, global warming, food vulnerability, water pollution, soil, air and social impacts such as economic, social, cultural (TUK Indonesia. 2015). Agrarian conflict will continue to occur here and there if the reasons are not eliminated with clear and definite steps (Noer Fauzi R. 2018). Although this location is the place to move the new capital, it remains a common question whether not to add to the problem in East Kalimantan with the presence of metropolitan cities. A city can build starting from the building management system, environmental quality management, as well as public services (Abdurrozzaq Hasibuan \& Oris Krianto Sulaiman 2019) even from the state sector as well, but about energy resources and ecosystem sustainability is the main issues that need to be addressed.

Based on these problems, this study tries to see the other side of the prima donna of palm oil utilization as the largest foreign exchange contributor in Indonesia (GAPKI 2017). What impacts this policy has on both the environment and social communities after the exploitation of land by oil palm plantations in East Kalimantan will be the subject of this paper. Because the state must not only vigorously build infrastructure, internet facilities, or business companies. It's all a complement to life, but don't let life itself be demeaned.

\section{Method.}

This study used the triangulation approach of both qualitative and quantitative methods. A survey was used to collect quantitative data from media users. Structured interviews were 
conducted with newspaper editors to collect qualitative data which provided detailed information on the current situation of newspapers in the face of digital platforms. Interviews allowed the researcher to gather in-depth data that questionnaires could not produce. The research population was the entire Namibian newspaper industry. The sample for this study was made up of editors from each of the two newspapers, The Namibian and New Era which were selected purposively using non-probability sampling techniques. Stratified random sampling was used to distribute 60 questionnaires to Windhoek residents of which 53 were answered and returned. Both qualitative and quantitative data analysis methods were used, content analysis was used to analyse the interviews and statistical tests in SPSS were used to analyse the survey data.

\section{Result and Discussion. \\ 1. Miscon Clarified Poverty}

The Wakil President of Indonesia, Ma'ruf Amin said as Chairman of the National Team for The Acceleration of Poverty Alleviation (TNP2K), said in his speech at the Indonesian Palm Oil Conference (IPOC) 2019 that palm oil has a role to alleviate poverty, hunger and open jobs for the community (MajalahSawitIndonesia.com 2019). The paradigm of poverty alleviation through the provision of jobs in oil palm by state officials was also pitched by coordinating minister for maritime affairs and investment Luhut Binsar Panjaitan, when the European Union made the Renewable Energy Directive II (RED II) agreement. In the agreement, the European Union agreed to stop the use of palm oil products as a daily necessity because it has an impact on the environment. Luhut strongly argues that the EU should review the policy because oil palm plantations help reduce poverty and open up public work space (finance.detik.com 2019). A year later Luhut gave a different opinion that the expansion of oil palm land in Papua is environmentally damaging and unfavorable to the community (katadata.co.id 2020). If palm oil can open up space for people to work, to earn wages, and alleviate poverty must be very profitable as he said in 2019.

The problem of poverty cannot be taken lightly by simply using the paradigm of poverty alleviation with companies as the leading sector to open jobs. Poverty is a multidimensional development problem (Ali Khomsan et al 2015). According to the National Bureau of Statistics poverty is seen as an inability from the economic side to meet the basic needs of food equivalent to 2100 calories per person per day and not food such as access to education, health, clothing, shelter, transportation and other goods or services.

For example, there are crisis situations such as those experienced by Venezuela as an oil country when the currency is of no value. When this happens the most valuable item is the basic necessity itself. Thus Poverty cannot be considered a condition of lack of nominal ownership of money, or ownership of formal work, but also failure to fulfill basic life rights, differences in treatment, access to science, technology and information. The general view is that it is poor when looking at an individual's work only as a farmer, with a simple house, but behind it he has farmland and production tools that can meet his basic needs without being able to afford to shop for the needs of agricultural products. The misclassification of poverty eventually led to a new problem, namely the shift in the living system of the people of East Kalimantan. 


\section{The Healing of The Living System in the Community}

Livelihood system is a livelihood system or strategy built by households, individuals or built by farmers (individual) households (groups), local organizations (social systems) in maintaining their lives in accordance with the prevailing social, economic, ecological, cultural and political circumstances in the region that ultimately make a picture of a community living system (Dharmawan 2007, Yulian 2017). This system of living is very important because before applying a new source of living as an example of palm oil commodities, there must have been an inherent system of plantation management in rural communities that proved bear centuries of guaranteeing the life of the community independently.

In maintaining the sustainability of the existing living system in the community, there are five aspects of capital that must be owned as a condition of production (Scoones 1998, Prihandini 2017). The five capitals are: (1) natural capital, is the sufficient availability of land, water content, and ecosystems contained in it, (2) physical capital, namely all assets that support production activities, (3) human capital, which is formed through the quality of knowledge, skills, and quantity of population in the region, (4) financial capital, namely the supply of consumption and operational needs, (5) social capital, this capital is an important basic capital as the foundation to meet each other's lives collectively collegial or mutual mutually meet the lives of the surrounding community.

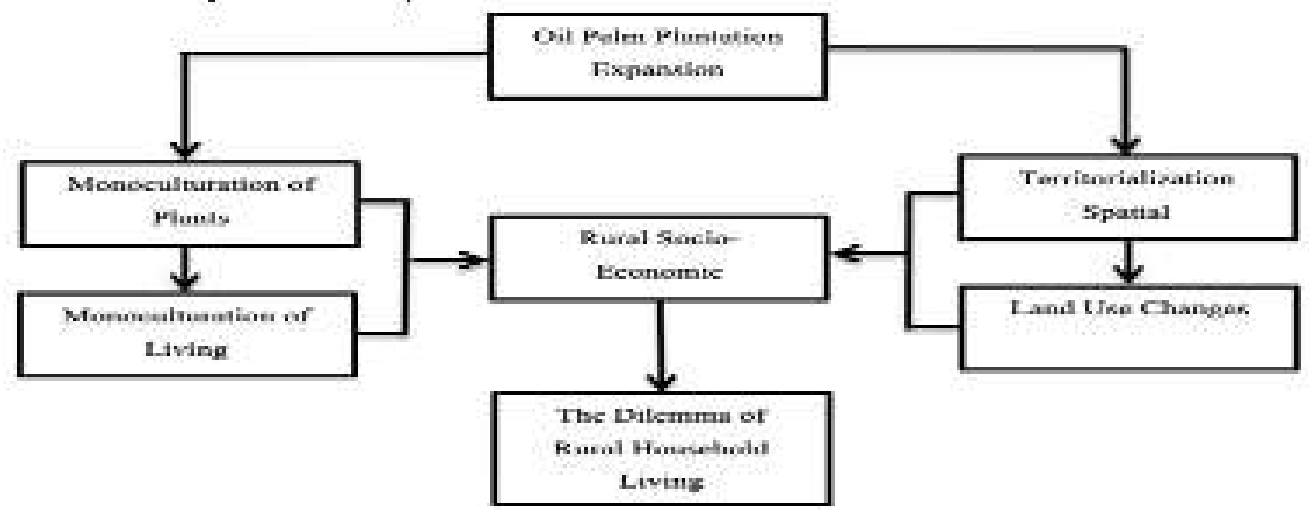

Figure 1. The cause of the dilemma of rural household living by the expansion of oil palm plantations (Source: Yulian et al 2017).

The picture above shows the concept of thinking when the expansion of oil palm plantations affects the mono culturation of plants. Single crop or monoculture is one way of cultivation by planting one type of plant in one area (Syahputra et al 2017). Then followed by the impact of single source of livelihood, namely dependence on one source of income. On the other hand, there is also spatial territorialization or land access restriction (Mahmud 2016) in this case in the form of narrowing the living space of rural communities and land transfer that leads to changes in household living. Then in looking at the concept of thinking can be attributed to the five capitals above. We can hypothesize that changes in the living system, especially in east Kalimantan, have a causality relationship to large monoculture plantations that are complex but sometimes unrecognized.

Geographically East Kalimantan is a prime area suitable for oil palm because it has a type of soil dominated by red-yellow podsolic latosol and litosol. Other soil types are organosol, alluvial, latosol, red yellow podsolic and podsol suitable for multicultural garden businesses, 
vegetables and forests. Biodiverisitas is a source of livelihood for the people in the villages because it has a diversity of plants that were previously a source of livelihood for the community and their lives are fulfilled by nature. For local people, especially dayak forest people have many meanings, not just forests but also as ulayat rights that must be maintained and have several functions, namely: 1.) forests as tribal ties, 2.) forests as a source of life consisting of farms, hunting grounds, life pharmacies, gathering places, and 3.) forests as sacred places or ancestral heritage (Samho \& Purwadi 2016).

Theliveli hoods of local people will never be far from nature, except those who already live in urban areas because life rests on salaries. For the local community itself the forest is a wealth, taking care of the forest is the same as we also automatically take care of the quality of water, animals in it, family economic resources, clean air, soil quality and others. This is the specialty of the forest. We take care and nature provides reciprocity in the form of garden products and animal consumption. This is the real source of life for the community and natural products can be a source of preservation of typical Kalimantan handicrafts in the form of woven mats, bead jewelry, wood carvings, spears, and others. that is how important the existence of forests for the community (Ibid.). When the land becomes a monoculture plantation with a single commodity of palm oil then the source of income of the community depends only on the climate of the palm oil market and becomes economically vulnerable to make the transformation of household living (Mardianingsih et al 2018).

The system change was evident in Kutai Kartanegara Regency. Palmoil plantations seem to provide welfare for rural households, open jobs, gardening communities themselves turn into oil palm farmers but what happens is the process of vulnerability and dependence of high incomes from the wages of oil palm plantations (Yulian et al 2017). The same thing also happened in Rawa Tabatan Baru Village, Kuripan District, Barito Kuala Regency, South Kalimantan that the welfare promised by the company for the presence of oil palm land was lost because only a small part can work there even though the community land taken is quite extensive. The people of Tabatan Village who work as farmers, farmers, wood seekers, fish finders, are now no longer able to continue these activities even the water around the village is polluted so as to force some residents to change the direction of the profession (WisnuSubroto 2018). The study that sampled 26 people in Muara Muntai Subdistrict, Kutai Kartanegara stated that 58\% of respondents said that the water condition became murky and 15\% even stated very murky because of the activities of PT oil palm plantations. IMM around them plus the existence of coal mining. Similar samples were also taken in Muara Kaman Sub-district with 26 respondents who also supported the opinion of other sub-districts, namely $69 \%$ of respondents stated that the water condition in Muara Kaman is currently more murky and 4\% stated very murky because of pt plantation activities. PMM related to both phenomena about the high water needs or absorption of oil palm that affects the surrounding residents (Nugroh \& Norhaq 2018)

In addition to making people dependent on palm oil commodities, it also creates vulnerabilities if palm commodity prices decline, this has not calculated the risk if it does not work anymore. The availability of basic materials that can be obtained in nature turned into something that eventually must be purchased by palm oil farmers. This form of land transfer can not be reginonal only occurs in East Kalimantan or Kalimantan region. But this is a system where this change occurs when the exploitation of land seizes the living space of the local community. As a system, of course similar cases will be easy to find in other regions in 
Indonesia. Examples of the same case can be found in Riau Province. Expansion oil palm around Tesso Nilo National Park has caused forests to degrade massively, the pattern of living of the people around the region changed to tend to be homogeneous with one source of living that is from monoculture plantations to oil palm (Nursanti Hidayah 2016).

As a system, oil palm plantations do not move on their own when raising their palm oil business in the local community. There is a local network that is also a support system to help the company's productivity. In the middle of the local community there is a local elite, the local elite that has an affiliation to the expansion of oil palm plantations is the one that has the human resources to control the land. Local elites are individuals or groups of people who have power, economic capabilities, technology, social capabilities that are influential at the regional level and in the case of oil palm plantations, the local elite utilizes small oil palm plantations of less than 25 hectares to encourage the productivity of core gardens both in terms of land clearing and selling crops to the core gardens (Purnomo 2016). This is one of the driving networks at the regional level that understands the social and field situation.

The situation that makes people directly or indirectly affected by the exploitation of oil palm that makes their land unproductive even forced to sell their land to large plantations, or those who become migrants of government transmigration programs and open up oil palm plantations make the formation of farmer typology. Research in Gunung Sari Village, Tabang District, Kutai Kartanegara Regency, East Kalimantan Province classified farmers into three typologies, namely plasma farmers, independent plasma farmers and independent farmers (Amalia 2019). Plasma farmers, namely oil palm farmers who manage land with the help of banks and facilitated by oil palm plantations then Fresh Bunches Fruit (BTS) must be sold to palm oil companies. Independent plasma farmers, namely plasma communities that increase production in their own land independently and BTS can sell on plantations through palm cooperatives or middlemen, usually the status of farmers' land in Gunung Sari Village is The Right to Business (HGU), Rights of Forest Entrepreneurs (HPH), or concessions of companies. The last is Independent Farmers, namely migrants who marry local residents then open palm oil plantations without plasma and sold through cooperatives or middlemen. These three typologies strongly indicate dependence on middlemen, cooperatives and even palm oil companies themselves called changes in living systems and economic vulnerability. This is the connection of the system between the local elite, oil palm farmers and small plantations that both live to support palm oil companies. Then, the social capital changes of farmers have also changed from communal to individual. Whereas the strategy of living and gardening culture in the village community proved centuries before the existence of palm oil has worked effectively and able to ensure the survival of the village household collectively collegial. Such social ties can sustain the family economy even in extreme situations.

With the mapping of this living system should be the foundation of the policy so that there is no disvergence of sources of living that make the dependence of people in East Kalimantan on oil palm or mining business. The implementation of a disverged development system by changing a land according to the wishes of the central government does not just happen once. Ideologi development of state centralism or state-style modernism is very strongly promoted and executed through government policies in the region when the new order era makes development inequality widen to make the area rich in natural resources only a catchment area that makes the problem of new poverty vulnerability with public facilities such as education and 
health are alarming (Ananda 2018). The dynamics written inthe book"Regional Economic Development: Dynamics and Development Strategies"by Candra Fajri Ananda can be seen happening outside java, especially in areas rich in Natural Resources (SDA).

The case that occurred in East Kalimantan and even South Kalimantan, and Riau Province is very contrary to the mandate of the Basic Law of 1945 "The earth and water and natural wealth contained therein are controlled by the state and used to the greatest extent for the prosperity of the people" (Article 33 paragraph 3) and "the national economy is organized based on economic democracy with the principle of togetherness, efficiency is fair, sustainable, environmentally sound, self-reliant, and by maintaining the balance of progress and national economic unity" (Article 33 Paragraph 4). in full, that is one of Indonesia's visions for social justice as outlined in the opening of the 1945 Constitution.

\section{Deforestation of East Kalimantan Forests}

According to Regulation of the Minister of Forestry No. 30 of 2009 concerning Procedures for Reducing Emissions From Deforestation and Forest Degradation (Redd) "Deforestation is a permanent change from forested to forestless areas caused by humane activitiesa". In a different sense, deforestation is the permanent or temporary loss of forest cover (Nawir 2008, Nahib 2015)

So what is the relationship between deforestation and oil palm plantations?. There are several activities indicated to be the cause of deforestation such as agricultural expansion, mining, plantations and transmigration, unsustainable forest management, illegal logging, and forest fires. The threat from deforestation is also due to the exploitation of oil palm plantations (Kamim 2018).

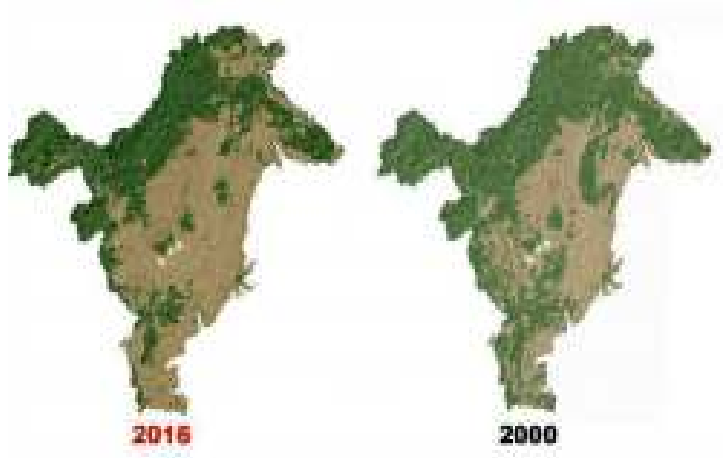

Figure 2. Changes in land cover and deforestation in East Kalimantan from 2000 to 2016 (Source: Forest Watch Indonesia 2018).

Pictured above is a portrait of land cover changes that occurred from 2000 to 2016. As a result of illegal logging, forest fires, and log sales efforts that have been in practice for a very long time making the area of forest in 2016 only $47 \%$ of the land area of East Kalimantan or

equivalent to 5.89 million hectares, and there has been deforestation of 472.00 hectares in just three years from 2013 to 2016. (FWI 2018). This has not been calculated with the overlapping area of licensing, the area of oil palm plantation permits, and the area of mining in East Kalimantan whose former mine pits can be seen from aircraft. Deforestation will continue to grow to this day if land use policy is not pursued.

Land transfer will not occur when the law does not open the tap of land clearing permits easily. The emergence of oil palm land clearing permits raises problems that can never be solved (Salim 2014). In 2019, an in-depth investigation using ArcGIS mapping tools showed East Kalimantan itself in the province with concession permits reaching 141 times the area of Jakarta (MiningAdvocacy Network 2019). Palm oil plantation companies expand their oil palm 
in the Area of Business Rights (HGU), while oil palm farmers expand oil palm plantations on their land or small plantations (Amalia 2016).

In addition to the problematic licens in gtaps, Expansion oil palm plantations are also conducted in forest areas illegally and informally (Hidayah 2016). In 2019, there will be 24 thousand hectares of illegal palm oil land in Berau Regency, East Kalimantan, which is located in the Area of Forest Management Rights (HPH). This finding is justified by the Vice Regent that the plantation has been continued in the forest area and not infrequently also the land owned by residents switched functions to plantation area (Tribunkaltim.com, 2019). There were 41 permits in Paser Regency covering 176,924,640 ha of oil palm plantations in 2013, but this figure does not include community-run independent oil palm plantations (Eddy 2017).

The change in land cover above is research taken from Gunung Sari Village, Kutai Kartanegara Regency. slowly in 1995-2005 then expanded to 2016. Seeing changes in addition to plantations, along with the expansion of oil palm plantations, apparent lyopen land and settlements also developed (Amalia 2019).

Related to the land use permit. During the reign of the new order there was logging known as kap flood where the government allowed the export of logs until there was a massive exploitation, then in 2005-2007 through a million hectare palm program made the East Kalimantan government open palm oil land in several districts (Amalia 2019). The widespread clearing of oil palm plantations resulted in changes in land function and resources that affect ecosystems and vegetation from land formerly peatlands (Risal 2018).

The threat of deforestation is also simultaneous with the impact of fires although the authors do not intend to point out that oil palm plantations play a role in forest fires. In 2020 alone East Kalimantan ranks third in the recapitulation of forest fires on the island of Kalimantan below the rank of West Kalimantan with a burned land area of 770 hectares and Central Kalimantan with an area of 725 hectares followed by East Kalimantan 348 hectares (Sipongi 2020). Several cases of forest fires occur in Kalimantan, including East Kalimantan, show that the majority of forest fires are in industrial plantation forests (HTI) which are nota bane part of the forest for palm oil development due to the cheaper land clearing process (Deni Bram 2013). The case that occurred in Loa Janan Village Kutai Kartanegara Regency occurred not because of nature as the cause, but is the residents themselves who are farmers and burn land because it is considered cheaper although there is no indication of involvement of palm oil companies, but the fact is still the private parties are not concerned about the incident (Irwandi et al 2016). Similar research also states that forest fires in East Kalimantan are the main cause of human factors (Danny 2001, Fachmi 2014) 

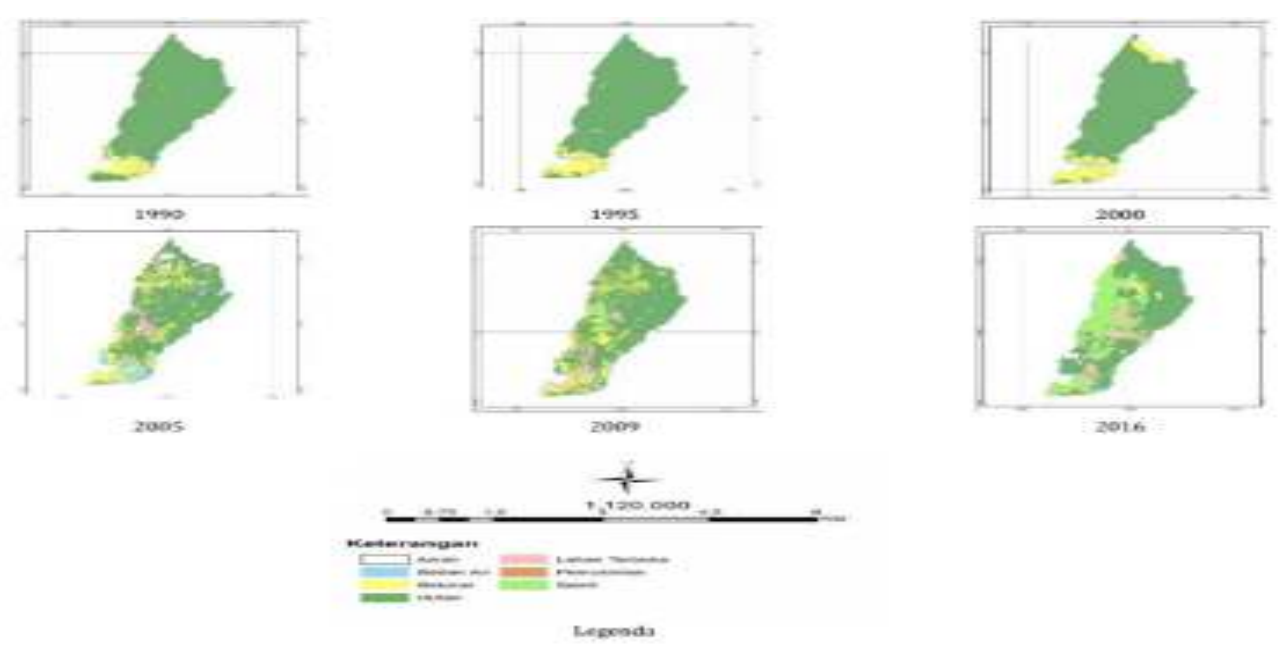

Figure 3. Changes inland cover in Gunung Sari Village, Tabang District, Kutai Kartanegara Regency, 2018 (Source: Amalia 2019).

Of course, this forest fire will have a huge impact on people's lives and the entire ecosystem in East Kalimantan. The impact taken in the middle of the price is murang and efficient by burning it is even very expensive when thinking about the long impact. Ecological damage, declining biodiversity, soil productivity, climate change, land economic value, respiratory tract infections, disrupting all modes of transportation, and even fires in East Kalimantan can be detrimental to other countries that are already seasonal disasters (Fachmi 2014). If there is a company that is proven to burn forests deliberately or employ local residents, cause pollution, and deforestation, it is certain that the company will be punished for the violation of Law No. 32/2009 on Environmental Protection and Management and Law No. 41/1999onForestry. But the fact that there are people who have asthma and have to spend money to get treatment is not an issue, as are the fatalities who died from ISPA. The fact that the impacts are so complex and not just about the natural environment is sometimes overlooked.

The impact of deforestation also affects indigenous peoples as well as local communities experience cultural degradation as well as local wisdom, traditions, art, especially those that depend on forests, rivers, lakes, agriculture, health and other circumstances. Recognition in the field is presented by Jahan who is a figure of Dayak Muluy Paser Tribe. Usually they can go to the forest to find rattan to make jewelry and even other items such as baskets, bags, and other foundations, but now it is very difficult even medicinal plants that can be used as traditional medicine when can not access the hospital is now difficult and depends on the location of hospitals or health centers far away, nature is no longer a library of life (Risal 2015).

\section{Conclusion.}

Based on the purpose of writing this journal that has been compiled in the introduction can be concluded 1.) That there has been a misconception of the meaning of poverty is simplified by clearing oil palm plantations so that the people of rural areas in East Kalimantan can get a job but in the midst of such efforts raises a new problem that is economic vulnerability. 2.) The area that becomes a place of exploitation of Natural Resources, especially in East Kalimantan is only a 
land of squeeze without being balanced with the fulfillment of health facilities, education and guarantee of a decent life on top of natural wealth that continues to be absorbed and can not enjoy its reciprocity properly 3.) There is a change in the system of people's livelihoods that could previously use plantation products with a multicultural system turned into a monoculture that makes the family's economic dependence on palm oil commodities so as to create vulnerabilities of new poor people who can not meet their basic needs. 4.) The exploitation system that has been built since the new order period makes forest deforestation increasing, loss of biodiversity, fauna, livelihoods of indigenous peoples, health problems and prolonged environmental pollution even more increasing every year. 5.) Utilization of natural resources is a natural thing but excessive utilization regardless of land suitability will make us enjoy what will not be enjoyed in the future

\section{References.}

Abdurrahim, A. Y., Dharmawan, A. H., Sunito, S., \& Sudiana, I. M. (2014). Kerentanan ekologi dan strategi penghidupan pertanian masyarakat desa persawahan tadah hujan di pantura Indramayu. Jurnal Kependudukan Indonesia, 9(1), 25-44.

Amalia, R., Dharmawan, A. H., Prasetyo, L. B., \& Pacheco, P. (2019). Perubahan Tutupan Lahan Akibat Ekspansi Perkebunan Kelapa Sawit: Dampak Sosial, Ekonomi dan Ekologi. Jurnal Ilmu Lingkungan, 17(1), 130-139.

Ananda, C. F. (2018). Pembangunan ekonomi daerah: dinamika dan strategi pembangunan. Universitas Brawijaya Press.

Angi, E. M., \& Wiati, C. B. (2017). Kajian Ekonomi Politik Deforestasi dan Degradasi Hutan dan Lahan di Kabupaten Paser, Kalimantan Timur. Jurnal Penelitian Ekosistem Dipterokarpa, 3(2), 63-80. DOI: http://dx.doi.org/10.20886/jped.2017.3.2. 63-80

Barri, M. F. (2018). Deforestasi tanpa henti: potret deforestasi di Sumatera Utara, Kalimantan Timur, dan Maluku Utara. Forest Watch Indonesia.

Bram, D. (2013). Kejahatan Korporasi dalam Pencemaran Lintas Batas Negara: Studi Pencemaran Kabut Asap Kebakaran Hutan di Indonesia, 11(3) 377-391.

CIFOR (2019). Apakah laju deforestasi di pulau Kalimantan melambat?. Diakses 1 Maret 2020. https://forestsnews.cifor.org/59433/apakah-laju-deforestasi-di-pulau-kalimantanmelambat? fnl $=$

Detik, Finance (2019) Luhut Sebut Sawit Kurangi Kemiskinan, Tapi Didiskriminasi Eropa.. Diakses 7 Mei 2020. https://finance.detik.com/industri/d-4476179/luhut-sebut-sawit-kurangikemiskinan-tapi-didiskriminasi-eropa.

GAPKI (2017). Sawit Konsisten Penyumbang Terbesar Devisa. Diakses 6 Maret 2020. https://gapki.id/news/1857/sawit-konsisten-penyumbang-terbesar-devisa.

Hasibuan, A., \& Sulaiman, O. K. (2019). Smart City, Konsep Kota Cerdas Sebagai Alternatif Penyelesaian Masalah Perkotaan Kabupaten/Kota, Di Kota-Kota Besar Provinsi Sumatera Utara. Buletin Utama Teknik, 14(2), 127-135.

Hidayah, N., Dharmawan, A. H., \& Barus, B. (2016). Ekspansi Perkebunan Kelapa Sawit Dan Perubahan Sosial Ekologi Pedesaan. Sodality: Jurnal Sosiologi Pedesaan, 4(3), 249-56.

INCAS (2015). Kalimantan Timur. Diakses 5 April 2020. http://incas.menlhk.go.id/id/data/eastkalimantan/.

Irwandi, J., \& Ismail, B. (2016). Upaya Penanggulangan Kebakaran Hutan Dan Lahan Di Desa Purwajaya Kecamatan Loa Janan Kabupaten Kutai Kertanegara Kalimantan Timur. Agrifor, 15(2), 201-210.

Jaringan Advokasi Tambang (2019) Siapa Penguasa Tanah Kaltim ?. Diakses 9 Mei 2020 
https://www.jatam.org/2019/03/08/siapa-penguasa-tanah-kaltim/.

Kamim, A. B. M. (2018). Perebutan Ruang Kehidupan dan Gangguan terhadap Animal Rights: Studi Atas Konflik Satwa-Manusia sebagai Implikasi dari Ekspansi Perkebunan Sawit di Indonesia. BALAIRUNG: Jurnal Multidisipliner Mahasiswa Indonesia, 1(2), 199-218.

Katadata (2020). Merusak Lingkungan, Luhut Larang Perluasan Lahan Kelapa Sawit di Papua. Diakses 7 Mei 2020. https://katadata.co.id/berita/2020/02/27/merusak-lingkungan-luhutlarang-perluasan-lahan-kelapa-sawit-di-papua

Kementerian Lingkuhan Hidup \& Kehutanan, R. I. (2018). Rekapitulasi luas kebakaran hutan dan $\begin{array}{lllll}\text { Lahan } & \text { (Ha) } & \text { per } & \text { tahun. Diakses } & \end{array}$ http://sipongi.menlhk.go.id/hotspot/luas_kebakaran

Khatun, R., Reza, M. I. H., Moniruzzaman, M., \& Yaakob, Z. (2017). Sustainable oil palm industry: The possibilities. Renewable and Sustainable Energy Reviews, 76, 608-619.

Khomsan, A., Dharmawan, A. H., Sukandar, D., \& Syarief, H. (2015). Indikator Kemiskinan dan Misklasifikasi Orang Miskin. Yayasan Pustaka Obor Indonesia.

Mahmud, A., Satria, A., \& Kinseng, R. A. (2016). Teritorialisasi Dan Konflik Nelayan Di Taman Nasional Bali Barat. Jurnal Sosial Ekonomi Kelautan dan Perikanan, 11(1), 45-54.

Mardiyaningsih, D. I., Dharmawan, A. H., Kolopaking, L. M., Firdaus, M., \& Nielsen, M. R. (2018). Livelihood Structure Transformation of Rural Communities: A Livelihood System Analysis of the Dayak Punan of Berau District, East Kalimantan, Indonesia. Journal of Economics and Sustainable Development, 9(18), 11-20.

Maulana, S (2019). Siapa Penguasa Tanah Kaltim ?. Diakses 1 Maret 2020. https://kaltimkece.id/warta/lingkungan/siapa-penguasa-tanah-kaltim

Nahib, I., Turmudi, T., \& Suwarno, Y. (2015). Pemodelan spasial deforestasi di kabupaten tasikmalaya, provinsi jawa barat. Majalah Ilmiah Globe, 17(2), 155-164.

Nugroho, A. E., \& Norhaq, R. (2018). Dampak Keberadaan Perkebunan Kelapa Sawit Pada Pembangunan Di Hulu Sungai Mahakam Kabupaten Kutai Kartanegara. Jurnal Magrobis, 18(2), 1-10.

Peraturan Menteri Sumber daya Mineral (ESDM) Republik Indonesia Nomor 41 tahun 2018

Prihandini, N. (2017). Identifikasi Modal (Sosial, Alam, Finansial, Fisik dan Manusia) Pada Dusun Wisata Sade Di Kabupaten Lombok Tengah. Jurnal Ilmiah Mahasiswa Feb, 6(1) 1494.

Purnomo, E.P. Nurmandi, A. Sulaksono, T. Hidayati,M. Ramdani, R. Agustiyara (2015) Ekologi Pemerintahan, Tata Kelola dan Kelembagaan Birokrasi dalam Menangani Kebakaran Hutan, Pengelolaan Sawit Serta Peranan Elit Lokal.

Rachman, N. F. (2018). Meninjau Kembali Teorisasi Mengenal Desentralisasi, Community Driven Delevopment, dan Kapitalisasi Agraria. BHUMI: Jurnal Agraria dan Pertanahan, 4(1), 1-23.

Rasyid, F. (2014). Permasalahan dan dampak kebakaran hutan. Jurnal Lingkar Widyaiswara, 1(4), 47-59.

Risal, M. (2018). Multinational Corporations (MNC) Perkebunan Kelapa Sawit Di Kalimantan Timur: Dampak Aspek Lingkungan, Sosial Budaya, dan Ekonomi. Jurnal Hubungan Internasional Interdependence, 3(1), 5-13.

Salim, M. N. (2014). Membaca Karakteristik dan Peta Gerakan Agraria Indonesia. BHUMI: Jurnal Agraria dan Pertanahan, 1(39), 405-426.

Sawit Indonesia (2019) Wapres RI: Sawit Dorong Pengentasan Kemiskinan. Diakses 20 April. https://sawitindonesia.com/wapres-ri-sawit-dorong-pengentasan-kemiskinan/

Sholikhah, A. (2016). Statistik Deskriptif dalam Penelitian Kualitatif. KOMUNIKA: Jurnal Dakwah dan Komunikasi, 10(2), 342-362. 
Subroto, W., \& Rochgiyanti, R. (2018, April). Perubahan struktur ekonomi masyarakat akibat masuknya perkebunan sawit di lahan rawa Desa Tabatan Baru, Kecamatan Kuripan, Kabupaten Barito Kuala, Kalimantan Selatan. In Prosiding Seminar Nasional Lingkungan Lahan Basah, 3 (2) 522-523.

Syahputra, N., Mawardati, M., \& Suryadi, S. (2017). Analisis Faktor Yang Mempengaruhi Petani Memilih Pola Tanam Pada Tanaman Perkebunan Di Desa Paya Palas Kecamatan Ranto Peureulak Kabupaten Aceh Timur. Agrifo: Jurnal Agribisnis Universitas Malikussaleh, 2(1), 41-49.

TUKIndonesia (2015). Dampak Kelapa Sawit. Diakses pada 6 Maret 2020 https://www.tuk.or.id/2015/01/22/dampak-kelapa-sawit/. Diakses 6 Maret 2020

Yulian, E. B., Dharmawan, A. H., Soetarto, E., \& Pacheco, P. (2017). Dilema Nafkah Rumahtangga Perdesaan Sekitar Perkebunan Kelapa Sawit di Kalimantan Timur. Jurnal].[Internet]. Jurnal Sosiologi Perdesaan, 5(3), 242-249 